\title{
MATHEMATICAL MODEL AND REGULATION OF THE TWO INTERCONNECTED VESSELS
}

\author{
Sergej GERAŠČENKO \\ Belarusian State Technological University, Minsk, Belarus \\ E-mail: gierasc@hotmail.com
}

\begin{abstract}
This article is about practical approach to the problem of cascade level-flow control and temperature regulation. PIcontroller designing practices for level-flow cascade control system are explained in this article. Heat exchange model between reservoirs, optimal control of temperature in the reservoir and finding of heater switch-over time are considered as well. Main purpose of such model is to explain temperature regulation method simultaneously with level regulation in the reservoir.
\end{abstract}

Keywords: cascade-control system, flow-level regulation, optimal control, pipelines.

\section{Introduction}

Cascade control systems are often used and perform better than a traditional single-loop conroller. The simplest case consists of the two control loops (inner loop and outer). Inner control loop in our case controls flow through the pumps. Outer control loop controls level in the reservoir.

Our system presented in Fig. 1 is designed to control defined level and temperature in the certain reservoir (Reservoir 2). A heating element is located in the first reservoir (Reservoir 1), while temperature and level are regulated ONLY in the second reservoir.

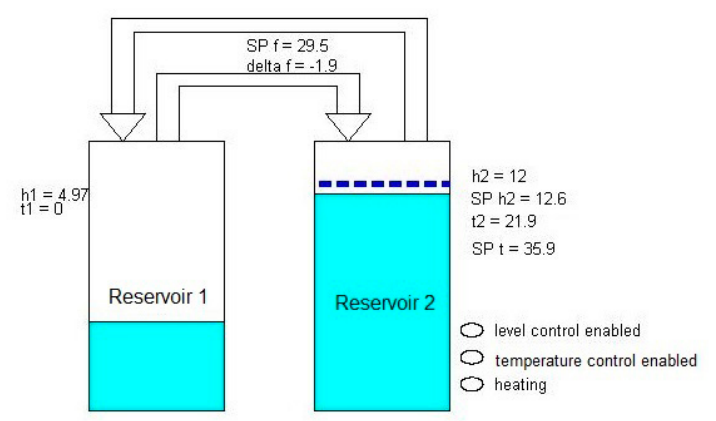

Fig. 1. Scheme of the cascade level-temperature control system. Controlled and measured variables: $h_{1}, h_{2}-$ levels in the Reservoir 1 and $2, \mathrm{~cm} ; t_{1}, t_{2}$ - temperature in the Reservoirs 1 and 2 respectively, ${ }^{\circ} \mathrm{C} ; S P t-$ set point of temperature in Reservoir $2,{ }^{\circ} \mathrm{C} ; f_{1}, f_{2}$ - flows from Reservoir 1 to Reservoir 2 and vice versa respectively, $\mathrm{ml} / \mathrm{s} ; \Delta f($ delta $f)-$ difference flow between input and output flow of the second reservoir, which is equal to $f_{1}-f_{2}, \mathrm{ml} / \mathrm{s} ; S P f$ - constant flow, provided between reservoirs, so that difference flow $\Delta f$ between reservoirs is maintained to be $0, \mathrm{ml} / \mathrm{s}$
Water pumped by the pumps runs from Reservoir 1 to Reservoir 2 and vice versa. Such model may be applied in water pools, chemical processes.

There are also control buttons (level control enabled, temperature control enabled), heating indicator in control application. Level set point may be set via double-clicking on the reservoir. Temperature set point is set in Simulink schema.

Measured and control variables are sent and received via Matlab/Simulink programs, which are connected to Arduino OPC Server.

\section{Hydraulics and electronic control of pump}

There are used mini brushless direct current pumps in our assembly. Hydraulics characteristics are presented in the following plot (Fig. 2).

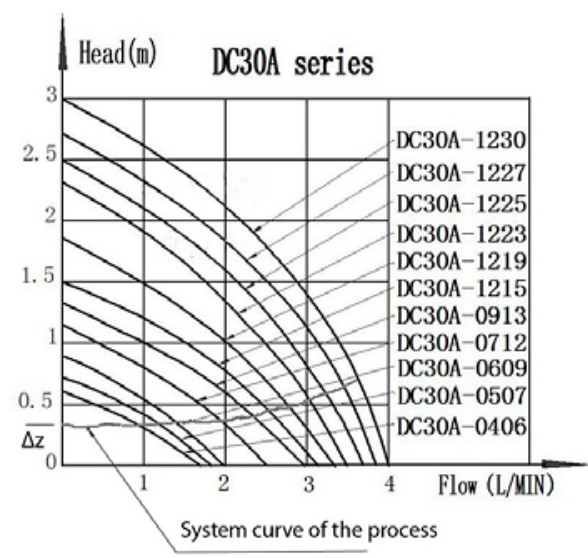

Fig. 2. System curve of the process and pump curves DC30A-xxxx (pointed out by arrows) 


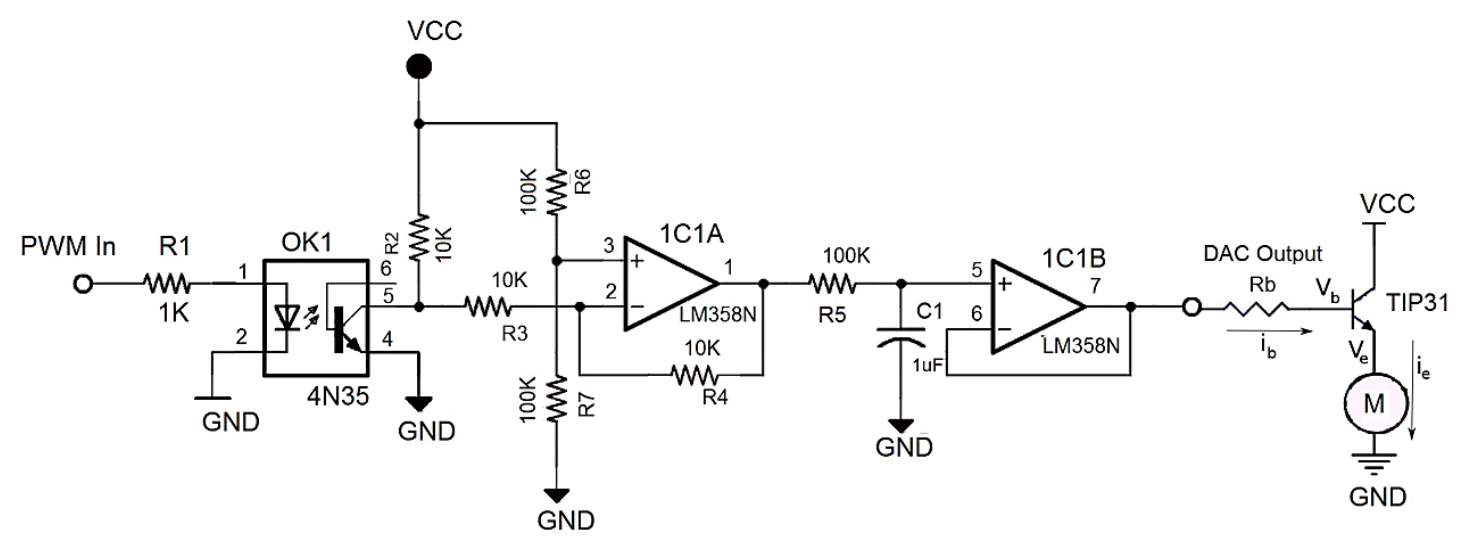

Fig. 3. Electronic scheme of pump control

There are series of pumps ranging by maximum flow $(1 / \mathrm{min})$ and maximum head (m). Pumps used in our assembly are of type DC30A-1230. That means supplied voltage $12 \mathrm{~V}$ and maximum head is $3 \mathrm{~m}$. Pumps are controlled by changing of direct voltage from 5-6 V to $12 \mathrm{~V}$. Pump curve shifts closer to $(0,0)$ point whenever supplied voltage decreases.

Pump curve DC30A-1230 is represented in the polynomial view:

$$
H_{p}=H_{0}-C_{1} Q-C_{2} Q^{2},
$$

here: $H_{p}$ - total dynamic head, $\mathrm{m} ; H_{0}$ - shutoff head (head at $Q=0), \mathrm{m} ; C_{1}$ and $C_{2}$ are constants evaluated for pump curve; $Q-$ flow, $\mathrm{ml} / \mathrm{s}$.

Pump head is written as follows:

$$
H_{f}=C Q^{2}+\Delta z
$$

where (Tullis 1989)

$$
C=\left(\sum \frac{f L}{2 g d A^{2}}+\sum \frac{K_{l}}{2 g A^{2}}\right),
$$

here: $\Delta z$ - static lift, $\mathrm{m} ; C-$ minor losses; $L-$ length of pipe, $\mathrm{m} ; d$-diameter $r, \mathrm{~m} ; A$ - sectional area of the pipe, $\mathrm{m}^{2} ; f$ - friction factor; $g$ - gravitational acceleration, $\mathrm{m} / \mathrm{s}^{2}$, $K_{1}-$ loss coefficient.

Making equal pump head $\left(H_{f}\right)$ to total dynamic head $\left(H_{p}\right)\left(H_{p}=H_{f}\right)$ we may obtain current operation point $\left(Q_{0}, H_{0}\right)$.

Pumps are controlled, as noted above, by direct voltage from 5-6 to $12 \mathrm{~V}$. As shown in the Fig. 3, PWM signal $0-5 \mathrm{~V}$ comes to input of an optocoupler. The optocoupler translates PWM signal from $0-5 \mathrm{~V}$ to $0-\left(12+U_{b e}\right) \mathrm{V}$, then voltage is followed by the operational amplifier. Next, by using RC-circuit, voltage is converted to direct. RC-circuit is matched to fit with PWM-frequency. Voltage signal is the second time followed by the operational amplifier and fed into the base of an emitter follower.
Voltage must be converted to direct, because a brushless motor of the pump requires only direct rectified voltage.

However we have collected not linear flow-PWM code characteristic (Fig. 4).

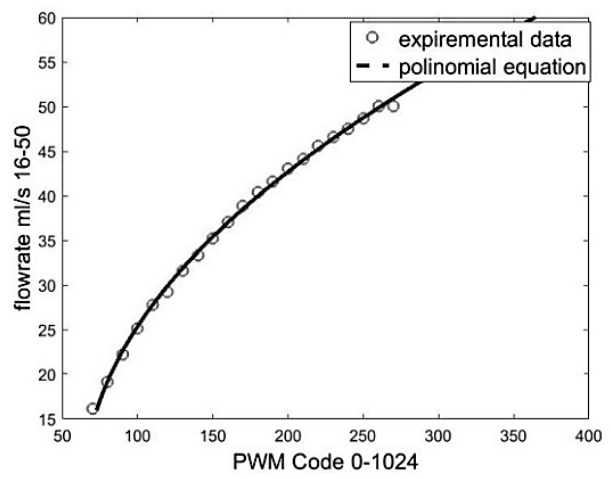

Fig. 4. Flow-PWM code characteristic: flowrate - flow through the pump, $\mathrm{ml} / \mathrm{s}, 16 \ldots 50$; PWM code - code applied to the input of an optocoupler for control

Control scheme of pump regulation has the following view (Fig. 5):

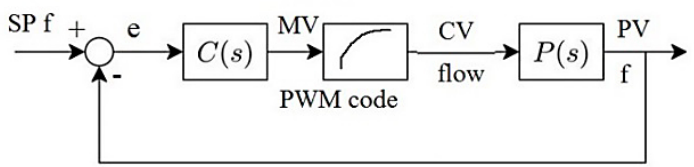

Fig. 5. Control scheme of pump regulation: $\mathrm{PV}(f)-$ flow process variable, $\mathrm{ml} / \mathrm{s} ; \mathrm{SP}(f)$ - set point flow, $\mathrm{ml} / \mathrm{s} ; \mathrm{MV}(\mathrm{PWM}$ code) - manipulated variable, $0 \ldots 1023$; $\mathrm{CV}$ (flow) - flow control variable, $\mathrm{ml} / \mathrm{s} ; \mathrm{e}-$ loop error signal, $\mathrm{ml} / \mathrm{s} ; C(s)-$ controller; $\mathrm{P}(\mathrm{s})$ - plant (pump)

Transfer function of the pump:

$$
P(s)=\frac{1}{0.1 s+1} .
$$

Rearranging (4) into differential equation gives:

$$
0.1 \frac{d F}{d t}=\left(k \cdot p w m^{2}+b \cdot p w m+c\right)-F,
$$

here: $p w m$ is PWM DAC code; $F-$ flow, $\mathrm{ml} / \mathrm{s}$; 
where nonlinear element is represented in the polynomial view. Applying Taylor series (Seborg et al. 2011):

$$
f(y, u) \cong f(\bar{y}, \bar{u})+\left.\frac{\partial f}{\partial y}\right|_{\bar{y}, \bar{u}}(y-\bar{y})+\left.\frac{\partial f}{\partial u}\right|_{\bar{y}, \bar{u}},
$$

where $y=F, u=p w m$.

Then after substituting:

$$
\begin{gathered}
0.1 \frac{d F^{\prime}}{d t}=(2 k \cdot p w \bar{m}+b) p w m^{\prime}-F^{\prime}, \\
\frac{F^{\prime}}{p w m^{\prime}}=\frac{(2 k \cdot p w \bar{m}+b)}{0.1 p+1} .
\end{gathered}
$$

The deviation variables $F^{\prime}$ and $p w \bar{m}$ are:

$$
\begin{aligned}
& F^{\prime}=F-\bar{F}, \\
& p w m^{\prime}=p w m-p w \bar{m},
\end{aligned}
$$

where: $\bar{F}, p w \bar{m}$ - steady-state values of variables.

\section{Discrete PI-controller and Anti-Windup techniques}

Discrete PI-controller of pump has the following view:

$$
u(k)=P e(k)+I \cdot T_{s} \cdot e(k)+u(k-1),
$$

here: $P$ - proportional term; $I$ - integral term; $T_{s}$ - sampling period; $e(k)$ - loop error signal; $u(k)$ - control variable.

As long as we use PI controller, we approach with an integrator windup. It is applied anti-windup techniques such as back-calculation or clamping to avoid anti-windup.

Back-calculation anti-windup signal, whose route is shown in the Fig. 6, may be written:

$$
u_{2}[i]=u_{2}[i-1]+\left(u_{3}[i-1]-u_{2}[i-1]\right) \cdot K_{\mathrm{b}} \cdot T_{\mathrm{s}}
$$

here: $u_{3}$ - control signal after saturation, $u_{2}$ - control signal behind saturation, $K_{\mathrm{b}}$ - back-calculation coefficient, $T_{\mathrm{s}}-$ sampling period.

\section{Level regulation}

There are different types of controller performance depending on tuning criteria. Two of them are known as averaging and tight level control described in (King 2011). The general demand in applying of cascade control is that the secondary loop should be able to detect and resolve any disturbance before the primary. Tight level control is required in situations where holding the level close to its SP has greater importance than maintaining a steady manipulated flow. Averaging level control is required in situations where keeping the manipulated flow as steady as possible is more important than keeping the level at its SP.

Controller tuning for tight-level control is derived by first assuming that we apply a proportional-only controller:

$$
\Delta M=K_{c}\left(E_{n}-E_{n-1}\right),
$$

here: $E_{n}-$ is an error signal.

Let us assume, that before flow disturbance, the level is at steady-state and SP, i. e. $E_{n-1}=0$. Since the flow imbalance $(f)$ will have existed for one controller scan interval $\left(t_{s}\right)$, the current error (in dimensionless form) is given by:

$$
E_{n}=\frac{f \cdot T_{s}}{V}, \quad \Delta M=\frac{f}{F},
$$

here: $V$-working volume, $\mathrm{ml} ; F$-flow range, $\mathrm{ml} / \mathrm{s}$.

In order to bring the level back to steady state we need to restore the flow balance and so the controller must change the manipulated flow by the flow disturbance $(f)$. From the two previous equations we can derive the largest possible controller gain.

$$
K_{\max }=\frac{V}{F \cdot T_{S}}
$$

The disadvantage of P-controller is an offset. That means that SP will never be reached and overcontrol may present, hence integral action may be added.

We first determine a reservoir time constant $(T)$ - measured with no controls in place. This is defined as the time taken for the level to change by the permitted deviation $(d)$ following the flow disturbance $(f)$. It is given by:

$$
T=\frac{V d}{100 f} \text {. }
$$

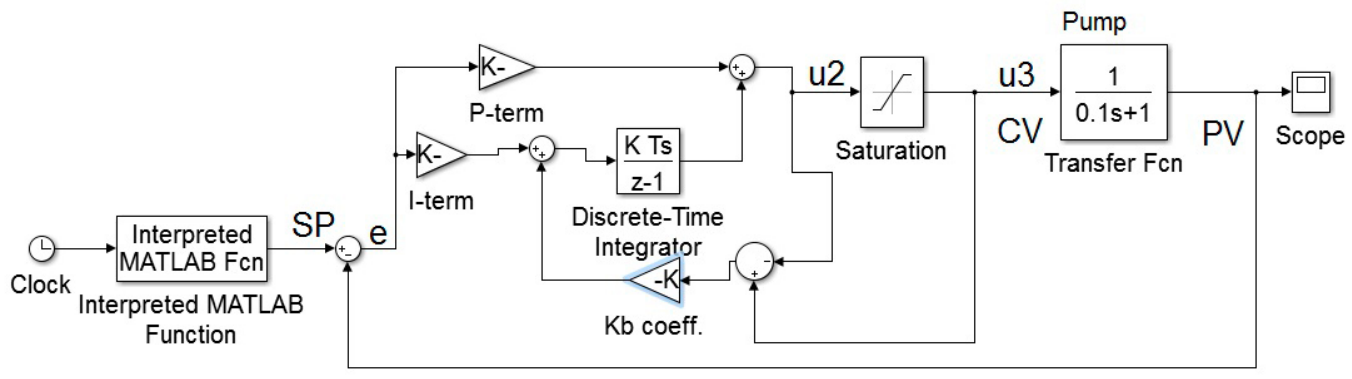

Fig. 6. Control scheme of pump: $u_{3}-$ control signal after saturation, $u_{2}$ - control signal behind saturation, $K_{\mathrm{b}}$ - back-calculation coefficient, $T_{\mathrm{s}}-$ sampling period 
Since we require tight level control, we would select a very small value for $d$, for example $1 \%$. Empirically, setting $T_{i}$ to $8 T$ will give good control performance.

Compensation for the addition of integral action should be made by reducing proportional action. Again empirically, applying a factor of 0.8 to $K \max$ works well

$$
K_{\max }=\frac{0.8 \mathrm{~V}}{F \cdot T s}, \quad T_{i}=\frac{V d}{12.5 f} .
$$

Height $(\mathrm{cm})$, difference between flows or delta-flow $(\mathrm{ml} / \mathrm{s})$ and error $(\mathrm{cm})$ plots for tight level control are shown in a Fig. 7.

The average control method used to tune the controller is very similar to tight level control. We start as before with a proportional-only controller.

$$
\begin{aligned}
& \Delta M=K_{c}\left[\left(E_{n}-E_{n-1}\right)+\left(E_{n-1}-E_{n-2}\right)+\ldots\right. \\
& \left.+\left(E_{1}-E_{0}\right)\right]=K_{c}\left(E_{n}-E_{0}\right) .
\end{aligned}
$$

We allow for an offset $d$ :

$$
E_{n}=\frac{d}{100},
$$

and combining equations (13), (17), (18):

$$
\begin{gathered}
K_{\min }=\frac{100 f}{F d} . \\
K_{\max }=\frac{80 f}{F d}, \quad T_{i}=\frac{V d}{12.5 f} .
\end{gathered}
$$

\section{Heat exchange model}

As spoken before, we have two interconnected reservoirs (Fig. 1). Stream circulate between them in both directions. Heater is located in the first (left) reservoir and temperature is controlled in the second (right) one.

We need to explain, how change of temperature in the first (left) reservoir influence onto the second (right) one. Let us assume that water in the second reservoir is ideally mixed. Then heat balance equation for the second reservoir will be written as follows:

$$
\Delta Q=\rho c\left[\Delta T_{1} F_{1}-\Delta T_{2} F_{2}\right] \Delta t
$$

here: $F_{1}$ is incoming stream, $\mathrm{ml} / \mathrm{s} ; F_{2}-$ outgoing stream, $\mathrm{ml} / \mathrm{s} ; \Delta T_{1}$ - temperature change in the first (left) reservoir, ${ }^{\circ} \mathrm{C} ; \Delta T_{2}$ - change of temperature in the controlled second (right) reservoir, ${ }^{\circ} \mathrm{C} ; \Delta Q$ - heat change in the controlled second (right) reservoir, $\mathrm{J} ; \rho$ - liquid density, $\mathrm{kg} / \mathrm{m}^{3} ; c$ heat capacity coefficient, $\mathrm{J} /\left(\mathrm{kg} \cdot{ }^{\circ} \mathrm{C}\right) ; \Delta t$ - time interval, sec.

But from the equation of specific heat:

$$
\Delta T_{2}=\frac{\Delta Q}{\rho c V_{0}},
$$

where: $V_{0}$ - working volume of the controlled second(right) reservoir, $\mathrm{ml}$.

Let us make equal $\Delta Q$ from (21) to $\Delta Q$ from (22) and differentiate by time left and right sides of given equation:

$$
V_{0} \frac{d \Delta T_{2}}{d t}=\Delta T_{1} F_{1}-\Delta T_{2} F_{2}
$$
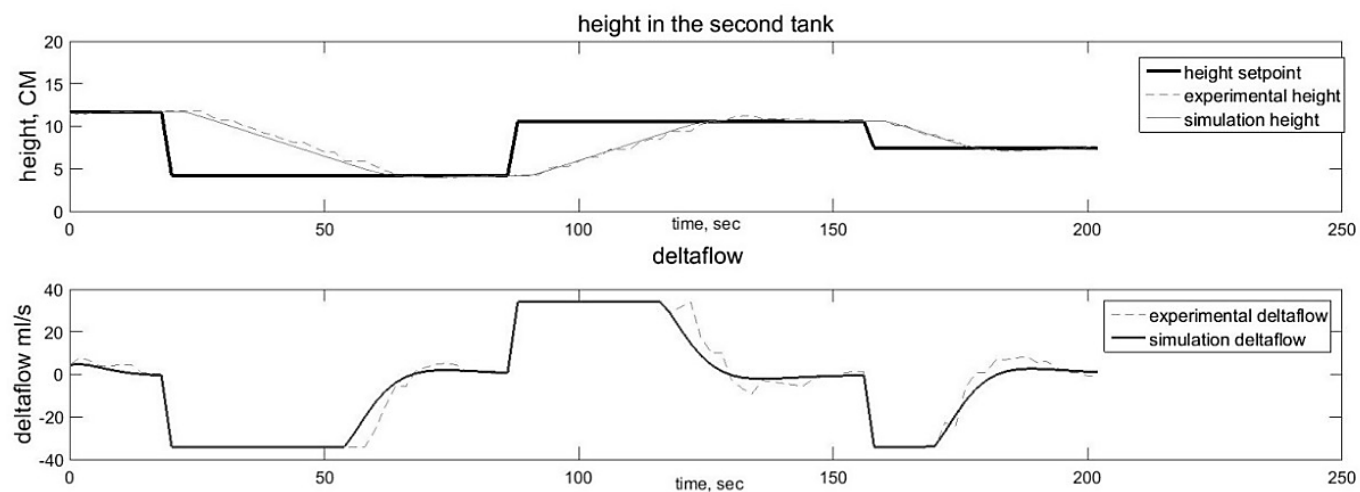

error height

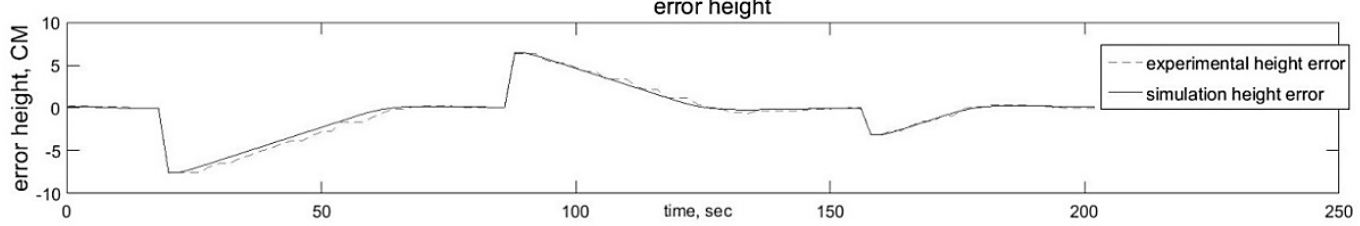

Fig. 7. Experimental and simulated data of the cascade level control system: height - regulated height in the second reservoir, cm; deltaflow $(\Delta \mathrm{f})$ - difference between input and output flows of the second reservoir, $\mathrm{ml} / \mathrm{s}$; height error - error between height set point and current flow process variable, $\mathrm{ml} / \mathrm{s}$ 
Finally, applying Laplace transformation, the following transfer function comes out:

$$
\frac{\Delta T_{2}}{\Delta T_{1}}=\frac{F_{1}}{p V_{0}+F_{2}} .
$$

For simplicity we will assume that $F=F_{1}=F_{2}, \Delta F=0$.

$$
\frac{\Delta T_{2}}{\Delta T_{1}}=\frac{1}{p \frac{V_{0}}{F}+1},
$$

where: constant time $T=V_{0} / F$.

Temperature sensor is described as the first order system with time constant equal to near $6 \mathrm{~s}$, which is much less than constant time of heat-exchange system.

\section{Optimal control of heat exchange system (Sivokhin, Meshcheryakov 2006)}

Let us rewrite transfer function (25) into the view of differential equation, assuming $\Delta T_{1}=\frac{P d t}{\mathrm{~cm}}$ :

$$
\frac{d \Delta T_{2}}{d t} \frac{V_{0}}{F}+\Delta T_{2}=\frac{P d t}{c m},
$$

here after, we differentiate (26) by time:

$$
\frac{d^{2} \Delta T_{2}}{d t^{2}} \frac{V_{0}}{F}+\frac{d \Delta T_{2}}{d t}=\frac{P}{c m},
$$

Taking from (27) $T=V_{0} / F-$ constant time; $U=P$ power, control variable; $k=1 /(\mathrm{cm}) ; \Delta T_{2}=x_{1}$; we have got a following differential equation:

$$
\ddot{x}_{1} T+\dot{x}_{1}=\frac{U}{k}
$$

Optimal control for the system (Fig. 8):

$$
u=\left\{\begin{array}{rc}
u_{\max }, & 0 \leq t \leq t_{1} \\
-u_{\min }, & t_{1}<t \leq t_{2}
\end{array}\right.
$$

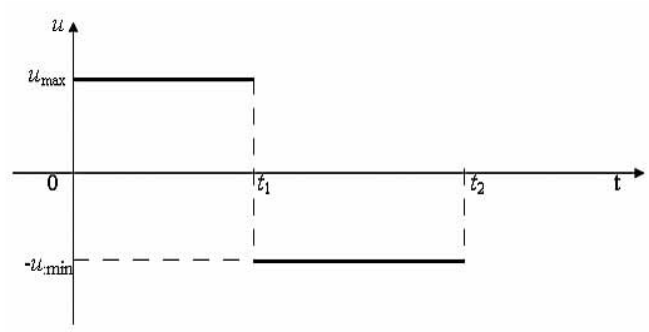

Fig. 8. Optimal control: $t_{1}$ is switch-over control point, s; $t_{2}$ - time for reaching to required change of temperature in the second (right) reservoir $x_{n}, \mathrm{~s} ; u_{\max }$ - heater power,

$$
\mathrm{W} ; \underline{u}_{\min }-\text { cooling power, } \mathrm{W}
$$

Homogeneous linear equation matching to (28) has the following view:

$$
\ddot{x}_{1} T+\dot{x}_{1}=0
$$

and characteristic equation matching to (28):

$$
\begin{aligned}
& T \cdot r^{2}+r=0, \\
& r_{1}=0, r_{2}=-\frac{t}{T} .
\end{aligned}
$$

Common solution for differential equation:

$$
x_{1}(t)=k u_{\max } t+c_{1}+c_{2} \exp \left(-\frac{t}{T}\right),
$$

Constants $c_{1}$ and $c_{2}$ we will find from the initial conditions: $\dot{x}_{1}(0)=0, \quad x_{1}(0)=0$ :

$$
c_{1}=-k u_{\max } T, c_{2}=k u_{\max } T
$$

Therefore, when $0 \leq t \leq t_{1}$ :

$$
\left\{\begin{array}{c}
x_{1}(t)=k \cdot u_{\max } \cdot t+k \cdot u_{\max } \cdot T \exp \left(-\frac{t}{T}-1\right), \\
\dot{x}_{1}(t)=k \cdot u_{\max }-\exp \left(-\frac{t}{T}\right) .
\end{array}\right.
$$

Similarly, we will solve differential equation for $u=-$ $u_{\text {min }}$, when heater is turned off and water is slowly cooling down:

$$
x_{1}(t)=-k u_{\min } t+c_{3}+c_{4} \exp \left(-\frac{t}{T}\right)
$$

Using terminal conditions $x_{1}\left(t_{2}\right)=x_{n}, \dot{x}_{1}\left(t_{2}\right)=0$, we will find constants $c_{3}$ and $c_{4}$ :

$$
\begin{gathered}
c_{3}=x_{n}+k \cdot u_{\min } \cdot t_{2}+k \cdot u_{\min } \cdot T, \\
c_{4}=-k \cdot u_{\min } \cdot T \cdot \exp \left(-\frac{t_{2}}{T}\right) .
\end{gathered}
$$

Then, when $t_{1} \leq t \leq t_{2}$, the solution of differential equation will be:

$$
\left\{\begin{array}{c}
x_{1}(t)=x_{n}+k \cdot u_{\max } \cdot\left(t_{2}-t+T-T \cdot \exp \left(\frac{t_{2}-t}{T}\right)\right), \\
\dot{x}_{1}(t)=k \cdot u_{\max } \cdot\left(\exp \left(\frac{t_{2}-t}{T}\right)-1\right) .
\end{array}\right.
$$

In order to find unknown variables $t_{1}$ and $t_{2}$ we will compute equations $\dot{x}_{1}(0)=0, \quad x_{1}(0)=0$ obtained both for $0 \leq t \leq t_{1}$ and $t_{1} \leq t \leq t_{2}$ conditions:

$$
\left\{\begin{array}{c}
k \cdot u_{\max } \cdot t_{1}+k \cdot u_{\max } \cdot T \cdot\left(\exp \left(-\frac{t_{1}}{T}\right)-1\right)= \\
=x_{n}+k \cdot u_{\min } \cdot\left(t_{2}-t_{1}+T-T \cdot \exp \left(\frac{t_{2}-t_{1}}{T}\right)\right), \\
k \cdot u_{\max }-k \cdot u_{\max } \cdot \exp \left(-\frac{t_{1}}{T}\right)= \\
=k \cdot u_{\min }\left(\exp \left(\frac{t_{2}-t_{1}}{T}\right)-1\right)
\end{array}\right.
$$



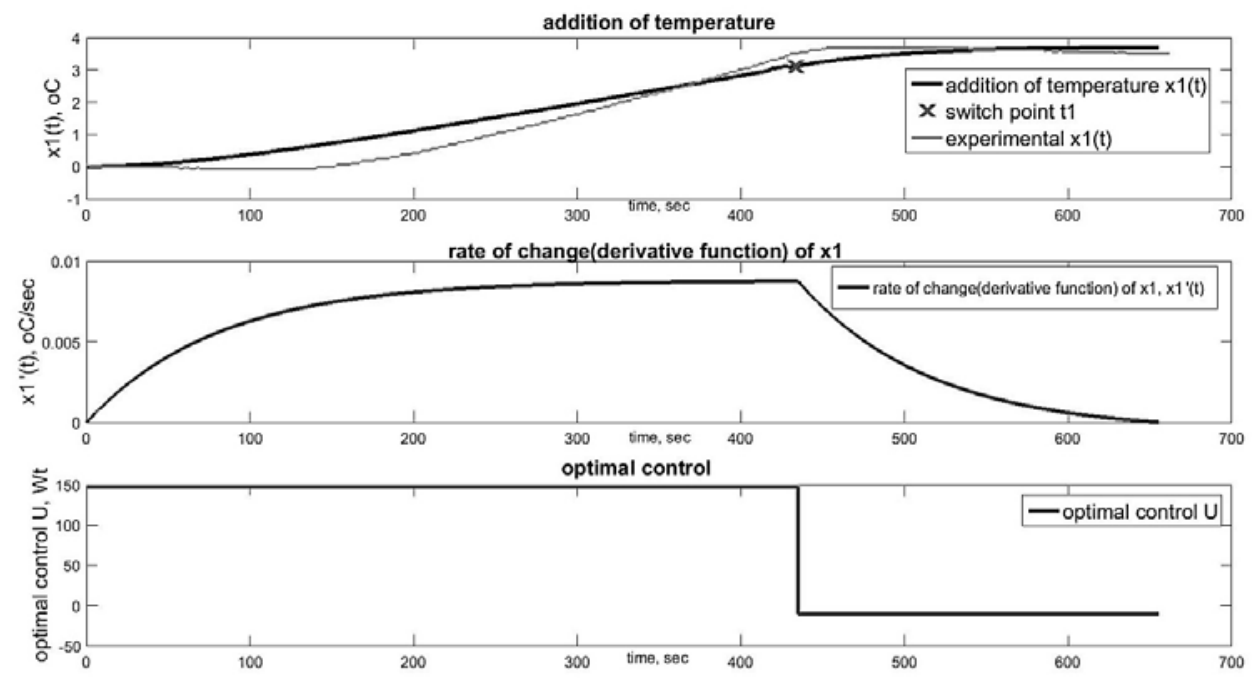

Fig. 9. Optimal control plots: $x_{1}(\mathrm{t})$ - function of addition of temperature in the second (right) reservoir, ${ }^{\circ} \mathrm{C} ; x_{1}{ }^{\prime}(\mathrm{t})-$ rate of change (derivative function) of $x_{1}(\mathrm{t}),{ }^{\circ} \mathrm{C} / \mathrm{s} ; U-$ optimal control of the heater, $\mathrm{W} ; t_{1}$ - switch-over point, $\mathrm{s}$

Taking $T=V_{0} / F=41 / 50 \mathrm{ml} / \mathrm{s}=80 \mathrm{~s}$; $k=1 /(\mathrm{c} \cdot \mathrm{m})=1 /(4 \cdot 4200) ; U_{\max }=150 \mathrm{~W} ; U_{\min }=10$ $\mathrm{W} ; x_{n}=3,7{ }^{\circ} \mathrm{C}$ and solving by Matlab tools, we find $t_{1}=434,9 \mathrm{~s} ; t_{2}=655,4 \mathrm{~s}$. That means when we need to put system $\left(x_{1}, \dot{x}_{1}\right)$ from point $(0 ; 0)$ into $\left(x_{n} ; 0\right)$, as it is plotted in a Fig. 9, we should provide control in described above way. $x_{n}$ is provided by stream exchanging required change of temperature in the second (right) reservoir.

\section{Conclusions}

Proximity of experimental values of level-flow control in the reservoir to simulated ones shows us that calculated parameters of PI-controllers, using proposed method, are suitable to our level-flow control process. Having solved equations of temperature optimal control, we may conclude that task of temperature control simultaneously with level control in the reservoir is fully solvable. But solving of the second-order differential and nonlinear equations, which has to be realized in a controller, complicates task of switch-over time finding. And for simplicity we pay no regard to distribution of temperature in reservoirs, considering reservoirs being ideally mixed.

\section{References}

King, M. 2011. Process control: a practical approach. Singapore: John Wiley \& Sons. 416 p. ISBN 978-0-470-97587-9. https://doi.org/10.1002/9780470976562

Seborg, D. E.; Mellichamp, D. A.; Edgar, T. F.; Doyle, F. J. 2011. Process dynamics and controls. 3rd ed. USA: John Wiley \& Sons. 595 p. ISBN 978-0-470-64610-6.

Sivokhin, A.V.; Meshcheryakov, B. K. 2006. Reshenie zadach optimal'nogo upravleniya s ispol'zova-niem matematicheskoy sistemy Matlab i paketa imi-tatsionnogo modelirovaniya Simulink. Penza: Penzenskiy gosudarstvennyy universitet. 263 p. In Russian.

Tullis, J. P. 1989. Hydraulics of pipelines: pumps, valves, cavitation, transients. New York: John Wiley \& Sons. 266 p. ISBN 0-471-83285-5. https://doi.org/10.1002/9780470172803

\section{DVIEJŲ TARPUSAVYJE SUJUNGTU REZERVUARU MATEMATINIS MODELIS IR VALDYMAS}

\section{S. Geraščenko}

\section{Santrauka}

Straipsnyje sprendžiama kaskadinio tèkmès lygio valdymo ir temperatūros reguliavimo tarp dviejų sujungtų rezervuarų problema. Pateikiami PI valdiklio kūrimo metodas skysčio tẻkmès lygiui valdyti, šilumos mainų tarp dviejų rezervuarų modelis, temperatūros valdymo šildytuvo veikimo laiko paieškos algoritmai. Pagrindinè darbo idejja - paaiškinti, kaip reguliuoti temperatūrą, tuo pačiu metu reguliuojant skysčio tèkmès lygi.

Reikšminiai žodžiai: kaskadinio valdymo sistema, tėkmės lygio ir temperatūros reguliavimas, optimalus valdymas, vamzdynai. 